\title{
Management Development Program to Increase Employee Capacity and Responsibility during the Covid-19 Pandemic
}

Rahis Rahman ${ }^{1}$, Mehmood Faheem ${ }^{1}$

Department of Economics, University of Karachi, Pakistan

Received: January 16, 2021

Revised: March 4, 2021

Accepted: March 17, 2021

\begin{abstract}
This article discusses the urgency of a management development program. A development principle that combines experiential learning, classroom learning and learning through others. The program development strategy can run well if it is accompanied by a well-planned human resource and capacity development program. So that it is expected to be able to help achieve the goals in producing high quality human resources. The human resource development strategy is a plan on how the quality of human resources can develop into a better direction and increase their work capacity. and have good loyalty to the company. Human resource development is needed for the continuity of a company so that it can develop more dynamically. because human resources are the most important element in a company.
\end{abstract}

Keywords: Management Development Program, Career Capacity, Employee Responsibility

\section{Introduction}

Management development program is a development program aimed at prospective employees who come from recruiting fresh graduates, who will be educated comprehensively, specifically in the business area. This development program provides career acceleration opportunities for selected university graduates to join our program. Through this development program, we aim to create competent individuals and potential leaders. Through this development program, each participant will be given the opportunity to learn new things in the scope of the financial industry, understand banking rules and regulations and experience firsthand how the banking business is run in a sustainable manner.

Apply the principles of compliance and applicable regulations. This program applies a development principle that combines experiential learning, classroom learning and learning through others. The biggest part of this development program will be obtained through on the job training activities where each participant will be directed and accompanied by Mentors who are senior managers, who are reliable and experienced in their fields (Roth \& Brooks-Gunn, 2003; Day, 2000). Office clusters are increasingly being highlighted by the development of Covid-19 cases among employees.

The most striking difference is definitely about interactions with other employees, because so far, when working in the office of fellow employees, direct interaction can be made, but because of the Covid-19 pandemic, it can only be done virtually both formally and informally. The formal meeting or meeting in question is like a meeting or discussion during the Covid-19 pandemic which is done virtually. Then an informal meeting, for example, wants to ask questions or chat with coworkers or even wish a fellow employee a happy birthday then blow out the candle, which was previously done by visiting a friend's table, but now it can only be done virtually. These two things are the most striking difference. 


\section{The Concept of Management Development Program in Increasing Capacity}

\section{Development Program Planning}

The program development strategy can run well if it is accompanied by a well-planned human resource and capacity development program (Torraco \& Swanson, 1995; Ubels et al., 2010). So that it is expected to be able to help achieve the goals in producing high quality human resources. Human Resources development program planning has several objectives, namely determining the quality of employees; Ensuring the availability of current and future employees; Minimizing the occurrence of errors in the implementation of work tasks; Facilitate the coordination process to improve employee performance optimally. Avoid the occurrence of excess or shortage of employees. Become a reference in the implementation of work tasks related to manpower. Become a guideline in determining employee recruitment, selection and discipline programs. Become a foundation in implementing employee appraisals.

\section{Steps for Making Human Resources Development Programs}

A well-planned human resource development program. The following are the steps you can follow to create a well-planned and well-planned human resource development program. The first step that must be taken is to determine and develop the goals, objectives, and priorities of the human resources needed. Making policies that support program socialization and implementation of human resource development programs. Projection of the availability of human resources, or estimate the number of employees needed and consider the needs of employees in the future (Baum, 2007; Jackson \& Schuler, 1990). Organizing employee skills training programs. If the steps for making the human resource development program above have been implemented, it is better if an evaluation is carried out first. This evaluation stage refers to the stages that have been made previously. This function is to predict whether the planned program will be successful or still need revision to perfect the next human resource development programs (Welbourne \& Andrews, 1996).

\section{Human Resource Development Strategy in the Company}

Human resource development strategies that can be carried out by companies include providing opportunities for every employee to channel their personal ideas and ideas (Schuler, 1992). Because in a company, employees also contribute in developing the company or as a cog of a company. So that the ideas and ideas of every employee also need to be heard and considered. Providing rewards (rewards) to employees, which aims to motivate other employees to be better. This will later make a major contribution to the company in developing the company. Organizing training programs for employees. There are several types of training and human resource development that can be done. Including skill training, retraining or retraining, cross functional training, team training, and creativity training.

Human resource development is an effort that can be made to form and produce quality people who have the skills, abilities and loyalty in carrying out their work in a company (Bowen \& Lawler 1992; Baron \& Armstrong, 2007; Lepak \& Snell, 1999). A strategy for developing human resources is very necessary considering that in the current era of technology, many companies are competing with each other to get a quality workforce (Torraco \& Swanson, 1995). Having quality employees is the biggest asset for the company.

\section{Increase the Capacity and Responsibility of Employees during the Covid Pandemic 19}

The human resource development strategy is a plan on how the quality of human resources can develop into a better direction and increase their work capacity (Wright, P. M., McMahan, G. C., \& McWilliams, A. (1994). And have good loyalty to the company. Human resource

Copyright @ 0 2021, Journal of Asian Multicultural Research for Economy and Management Study, Under the license CC BY-SA 4.0 
development is needed for the continuity of a company so that it can develop more dynamically. Because human resources are the most important element in a company.

Companies that can achieve success are companies that understand the importance of a human resource development strategy, and know what efforts must be taken (Guest, 1987). An employee's relationship with the company's leadership is not only tied to a work relationship. But humanly they also interact with each other. Therefore, human resource development can be used as a form of appreciation by a company leader for employees in a humane aspect. One of the aspects that can support the process of developing human resources is the aspect of education.

\section{HC \& GA Strategic Steps for Employees in the Midst of a Pandemic}

Then the activity of gathering with colleagues as a relief from fatigue, such as playing together or having lunch together, which do not only talk about work, at this time it cannot be done because we all work from home. From there, the HCGA team thought about how to be able to do the same thing even though working from home. So currently the HCGA team conducts an engagement activity at least once a month, both sharing knowledge and other matters that are not just a matter of work. Getting competent workers is a dream for HRD and the company. Competent workers can contribute greatly to accelerating company growth, so their existence is very important. Therefore, retaining competent employees is one of the biggest challenges for HRD practitioners. Moreover, during a pandemic like this time. Company conditions that may become unstable will trigger concerns from every worker. HRD must think specifically about how to retain the company's best employees to remain incorporated in the organization. It is possible that your competitors may also be targeting your best employees and may offer something better with all considerations in this pandemic.

If in normal circumstances retaining your best workers is a challenge in itself, doing it in an unfortunate situation like this pandemic is a different level. The main asset in the company to achieve company goals. The manager is the leader of the work unit in the company, to "make things happened". Managers who have sufficient competence will be able to bring their team to achieve high productivity and achieve their work goals effectively. Conversely, if there is a manager who is incompetent or has a weak mentality or bad morals, it will bring down the productivity of his team and is a loss for the company.

Managers must have "high competence, strong mentality and good morals". These competencies consist of Hard-Skill (Technical Skill) and Soft Skill (People Skill) competencies. Hard Skill competencies consist of skills: technical functional, business and managerial. Meanwhile, Soft skill competencies include Intra-Personal and Inter-Personal competencies, which are the foundation of Leadership. Managers must have equal competence in the Technical (work) competence required in their field of work and competence with "people". Managers must also have sufficient skills to be able to improve the mental and morale of their staff.

Front line managers are very critical to be given adequate and appropriate training. Managers must have a mindset that is structured, easy to understand, committed to working together, understand the steps that must be achieved, do good planning, build a team spirit, communication, etc. If the competence is sufficient, the manager will be able to carry out his duties effectively, in addition to developing his common sense abilities. Thus, managers will be able to more quickly develop their competences in the workplace.

As we know, many companies have been forced to reduce the number of employees as a result of the Covid-19 pandemic that has hit Indonesia. With many considerations, usually 
management is forced to release daily workers and not extend contract employees, leaving employees with more potential and employees who are senior and qualified.

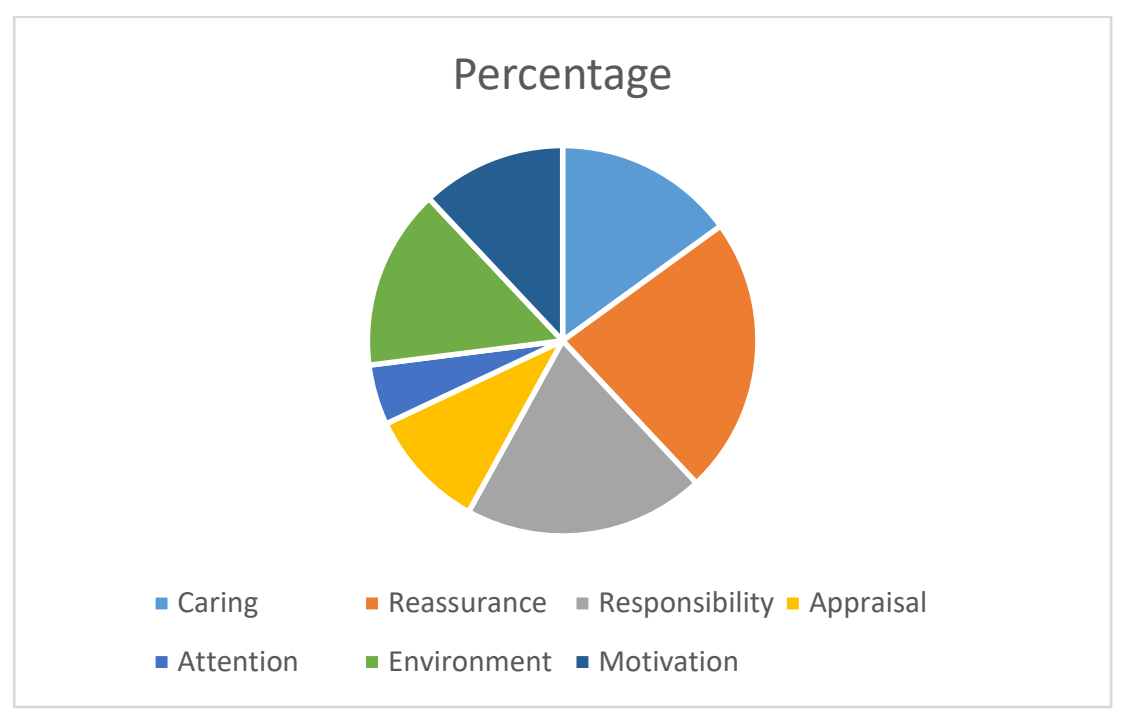

Figure 1. HC \& GA strategic steps for employees in the midst of a pandemic

\section{Caring}

Give them extra time to pay attention. Listen to the difficulties faced in completing work in the midst of limited conditions. If they work from home, provide office equipment and equipment to help them work more easily, such as pulses for communication, laptops with updated batteries, etc.

Make sure your best employees are still motivated to work, and most importantly, make sure you can bridge the needs of employees and the needs of the company well.

\section{Reassurance}

During a pandemic like this time, from management to the lowest layers of employees, they will feel anxious about uncertain conditions. The news that the frequent layoffs of employees will make employees nervous and think.

The first challenge for HR players in situations like this is to be able to provide convincing information to employees about the development of the situation in the company and to maintain communication in a friendly manner.

\section{Responsibility}

Show your best employees that the company believes in their ability to trust. Giving more responsibility to your employees will make these employees feel that their abilities are trusted by the company so that they psychologically will keep employees motivated to always give better performance. This is also a form of providing the support that employees need in developing themselves.

Employees who feel trusted by the company and have many opportunities to develop will certainly be more loyal to the company. In normal situations, there are many ideas that can be developed and tried so that the company is able to retain its best employees. Increasing wages, providing large incentives, annual bonuses, beneficial benefits for the family, are some of the things you can do to convince employees that working at your place is the best thing. 
Adding or providing better forms of benefits for employees is the most common way to increase employee motivation. Compete to provide better and more creative benefit models for your best employees, because your competitors may be offering better benefits for them than those already given.

\section{Highlight Appreciation and Appreciation}

Make it a habit to show appreciation for all forms of member services and give rewards to eligible employees is the most costless way to try. Of course, to feel the results will take a long time because this is a form of creating a good work culture.

The simplest giving of appreciation can be done by giving thorough attention to your members or coworkers while having a discussion. Regardless of how important the point of the discussion is, giving your full attention shows that you value your co-workers' time, effort, and willingness.

\section{Great Attention to Employee Development}

Invest extraordinary attention in the development of the potential of your employees (Maxwell, 1995). . Especially employees who show great potential to develop and contribute to company goals. Make sure your company has a training program and regular Q\&A to provide direction on employee capability development.

Remember that the development of an organization is never separated from the development of its human resources.

\section{Comfortable Environment}

A working space that is clean and "not suffocating" will more easily balance the stress levels that employees feel while working. Create a comfortable work environment by adjusting the company's capacity, employee character, and company values. Use ergonomic furniture, a pantry with enough space to store and make employee's favorite drink, or a lounge for a coffee break.

\section{Motivation and Healthy Competition}

Humans always want to grow and develop, reaching the highest possible target. Give them a reason and motivation to do it. Organize a series of events to create a competitive work environment and be able to unleash the potential that exists in employees.

\section{Conclusion}

Planning for Human Resources development programs has several objectives, namely: Determining the quality of employees, Ensuring the availability of employees at present and in the future, Minimizing the occurrence of errors in the implementation of work tasks, Facilitating the coordination process to improve employee performance optimally, Avoiding The occurrence of excess or lack of employees, Becomes a reference in the implementation of work tasks related to employment, Becomes a guide in determining employee recruitment, selection and discipline programs (Cook, 2008). The human resource development strategy is a plan on how the quality of human resources can develop into a better direction and increase the work capacity of the career people. and having good loyalty to the company is a very important benchmark in facing challenges during a pandemic. The company's financial capability can be a barrier to offering better compensation and benefits for your employees. However, as a person in charge of the human resource division, you can look for things that are more creative and essential for employees, of course, that don't have to spend a lot on the company.

Copyright @ 2021 , Journal of Asian Multicultural Research for Economy and Management Study, Under the license CC BY-SA 4.0 


\section{References}

Baron, A., \& Armstrong, M. (2007). Human capital management: achieving added value through people. Kogan Page Publishers.

Baum, T. (2007). Human resources in tourism: Still waiting for change. Tourism management, 28(6), 1383-1399.

Bowen, D. E., \& Lawler III, E. E. (1992). Total quality-oriented human resources management. Organizational dynamics, 20(4), 29-41.

Cook, S. (2008). The essential guide to employee engagement: better business performance through staff satisfaction. Kogan Page Publishers.

Day, D. V. (2000). Leadership development:: A review in context. The leadership quarterly, 11(4), 581-613.

Guest, D. E. (1987). Human resource management and industrial relations [1]. Journal of management Studies, 24(5), 503-521.

Jackson, S. E., \& Schuler, R. S. (1990). Human resource planning: Challenges for industrial/organizational psychologists. American psychologist, 45(2), 223.

Lepak, D. P., \& Snell, S. A. (1999). The human resource architecture: Toward a theory of human capital allocation and development. Academy of management review, 24(1), $31-48$.

Maxwell, J. C. (1995). Developing the leaders around you: How to help others reach their full potential. HarperCollins Leadership.

Roth, J. L., \& Brooks-Gunn, J. (2003). What exactly is a youth development program? Answers from research and practice. Applied developmental science, 7(2), 94-111.

Schuler, R. S. (1992). Strategic human resources management: Linking the people with the strategic needs of the business. Organizational dynamics, 21(1), 18-32.

Torraco, R. J., \& Swanson, R. A. (1995). The strategic roles of human resource development. Human resource planning, 18, 10-21.

Torraco, R. J., \& Swanson, R. A. (1995). The strategic roles of human resource development. Human resource planning, 18, 10-21.

Ubels, J., Acquaye-Baddoo, N. A., \& Fowler, A. (Eds.). (2010). Capacity development in practice. Earthscan.

Welbourne, T. M., \& Andrews, A. O. (1996). Predicting the performance of initial public offerings: should human resource management be in the equation?. Academy of management journal, 39(4), 891-919.

Wright, P. M., McMahan, G. C., \& McWilliams, A. (1994). Human resources and sustained competitive advantage: a resource-based perspective. International journal of human resource management, 5(2), 301-326. 